\title{
ODONTOID PROCESS HYPOPLASIA AND BIPARTITE ATLAS ASSOCIATED WITH ATLANTO-AXIAL INSTABILITY
}

\author{
HIPOPLASIA DO PROCESSO ODONTÓIDE E ATLAS BIPARTIDO ASSOCIADO \\ A INSTABILIDADE ATLANTO-AXIAL
}

HIPOPLASIA DE LA APÓFISIS ODONTOIDE Y ATLAS BIPARTITO ASOCIADO

CON INESTABILIDAD ATLANTOAXIAL

Luis Miguel Sousa Maroues ${ }^{1}$, Clara Romero ${ }^{1}$, José Gabriel Monteiro de Barros Cabral ${ }^{1}$

1. Hospital de Egas Moniz, Neurosurgery Service, Lisbon, Portugal.

\begin{abstract}
Surgical treatment of craniocervical junction pathology has evolved considerably in recent years with the implementation of short fixation techniques rather than long occipito-cervical fixation (sub-axial). It is often difficult and sometimes misleading to determine the particular bone and vascular features (high riding vertebral artery, for instance) using only the conventional images in three orthogonal planes (axial, sagittal and coronal). The authors describe a rare clinical case of congenital malformation of the craniovertebral junction consisting of hypoplasia/agenesis of the odontoid process and bipartite atlas associated with atlantoaxial instability which was diagnosed late in life in a patient with a previous history of rheumatologic disease. The authors refer to the diagnostic process, including new imaging techniques, and three-dimensional multiplanar reconstruction. The authors also discuss the surgical technique and possible alternatives.
\end{abstract}

Keywords: Congenital abnormalities; Cervical atlas; Cervical vertebrae; Odontoid process.

\section{RESUMO}

O tratamento cirúrgico da patologia da charneira crânio-cenvical tem evoluído consideravelmente nos últimos anos com a implementação de técnicas de fixação curta em detrimento de longas fixações occipito-cervicais (sub-axiais). Frequentemente é diffícil e por vezes enganador determinar as variações ósseas e vasculares (artéria vertebral high-riding p.e.) apenas pelas imagens convencionais em três planos ortogonais (axial, sagital e coronal). Os autores descrevem um caso clínico raro de malformação congénita da charneira crânio-cervical constituída por hipoplasia/agenésia da odontoide e atlas bipartido, associado a instabilidade atlanto-axial e diagnosticado tardiamente em doente com antecedentes reumáticos prévios. Descreve-se o processo diagnóstico, incluindo novas técnicas de imagiologia e de reconstrução multiplanar tridimensional. Discute-se a técnica cirúrgica utilizada e possíveis alternativas.

Descritores: Anormalidades congênitas; Atlas cervical; vertebras cervicais; Processo odontoide.

\section{RESUMEN}

El tratamiento quirúrgico de la patología de la región craneocenvical ha evolucionado considerablemente en los últimos años con la aplicación de técnicas de fijación cortas en lugar de fijación occipito-cervical larga (sub-axial). A menudo es difícil y hasta engañoso determinar las características óseos y vasculares (arteria vertebral high-riding, por ejemplo) usando sólo imágenes convencionales en tres planos ortogonales (axial, sagital y coronal). Los autores describen un caso clínico poco frecuente de malformación congénita de la unión craneocervical que consiste en la hipoplasia/agenesia de la apófisis odontoides y atlas bipartito, asociado con la inestabilidad atlantoaxial, diagnosticado tardiamente en pacientes con enfermedades reumatológicas previas. Los autores relatan el proceso de diagnóstico, incluyendo nuevas técnicas de imagen y la reconstrucción multiplanar tridimensional. Los autores también discuten la técnica quirúrgica y las posibles alternativas.

Descriptores: Anomalías congénitas; Atlas cervical, Vértebras cervicales; Apófisis odontoides.

\section{INTRODUCTION}

Congenital malformations of the craniocervical junction are rare and often diagnosed incidentally. In the presence of chronic bulbomedullary compression, the diagnosis is usually late (a high clinical suspicion being fundamental) or achieved following an acute event, particularly a traumatic one.

The surgical approach (anterior or posterior) to the craniocervical junction, particularly in atlantoaxial instability/luxation, depends on the reducibility of the luxation. ${ }^{1}$
In most cases, the adoption of short posterior vertebral fixation techniques $^{2}$ (C1-C2) has replaced long occipital-cervical fixation (sub-axial) with good clinical outcomes and the preservation, in large part, of cervical mobility, although with an increased risk of neuro-vascular lesions, particularly of the vertebral artery. The need to extend the fixation to the occipital bone, which may increase the stability of the fixation and improve the clinical outcome, has also been questioned in pure atlantoaxial instabilities.

Clinical Case: A 62-year old female patient with a personal history of rheumatoid arthritis, Sjögren's syndrome, chronic thyroiditis 
(autoimmune), anemia, and degenerative musculoskeletal disease (bilateral coxarthrosis and supraspinatus rupture). She was regularly followed up by a rheumatologist and had multiple hospitalizations following episodes of worsening rheumatic disease.

About a year and a half before the referral to our Neurosurgery Department, the patient reported a fall from the standing position that resulted in tetraparesis with an inability to walk or to perform activities, including feeding herself. It was initially considered a polyarthritis flare given the rheumatologic precedents. There was clinical improvement following prolonged physiotherapy, with partial recovery. At that time, the patient could walk semiautonomously, but with the assistance of forearm crutches, despite mechanical-type axial cervicalgia.

Upon receiving the results of electromyography (EMG) performed in the outpatient clinic compatible with "signs of compromise to the 1st neuron/spinal lesion", she was referred for consultation to Neurology, which in turn identified mild tetraparesis (predominantly left), with a drop (to the left) in the extended arms and Mingazzini tests, very brisk osteotendinous reflexes (OTR) over an extended area, the presence bilaterally of the exhaustible Achilles reflex and the extensor cutaneous-plantar reflex (CPR).

The imaging evaluation (CAT and MRI of the cervical spine) revealed a complex malformation of the craniocervical junction with the presence of central fusion defect of the anterior and posterior arch of the atlas (called rachischisis of the atlas, bifid atlas or Currarino type A bipartite atlas), ,3 associated with odontoid process hypoplasia. Severe atlantoaxial luxation with an increase in the space between the anterior arch of $\mathrm{C} 1$ and the odontoid process (ADI atlanto-dens interval $-9.7 \mathrm{~mm}$ ) and a reduction in the diameter of the vertebral canal (PADI - posterior atlanto-dens interval - around $8 \mathrm{~mm}$, also called SAC - space available for the cord) with signs of severe spinal compression (Figure 1A-E).

Imaging evidence of "signs of arthrodesis between the lateral masses of the atlas and the axis, especially on the left" (figure 1D) and "possible fusion of the posterior arch of the atlas to the occipital bone" was reported by Neuroradiology, which could mean that the atlantoaxial luxation would de irreducible with consequences relative to the treatment and surgical approach. In the detailed analysis of the MRI images the presence of a hypersignal on the left between the C1-C2 articular facets (Figures 2A-B) stood out, which could indicate the presence of intra-articular fluid and, therefore, counter the hypothesis of fusion between both joints.

Then, dynamic radiography and CAT were performed in a neutral position and in hyper-extension (not performed in hyper-flexion because of the potential neurological risk) and confirmed the total reduction of atlantoaxial luxation and the existence of atlantoaxial instability (Figure 3A-B) and the absence of fusion of the posterior arch of the atlas to the occipital bone.

Posterior approach atlantoaxial fixation surgery was performed with the placement of $4 \mathrm{~mm} \times 28 \mathrm{~mm}$ screws in the lateral masses of $\mathrm{C} 1,{ }^{5,6}$ and $4 \mathrm{~mm} \times 36 \mathrm{~mm}$ crossing translaminar screws in C2 (Wright technique), ${ }^{7,8}$ with no intercurrences reported. (Figure 4A-F) The pedicle fixation technique was not used in C2 (properly speaking, the Harms/Goel technique) because of the presence of a moderately high-riding left vertebral artery. This was done following a threedimensional multiplane reconstruction using OsiriX ${ }^{\mathrm{TM}}$ software, a technique that our group has often used. ${ }^{9}$ (Figure $5 \mathrm{~A}-\mathrm{C}$ ) The coaptation between the occipital condyles and the lateral masses of $\mathrm{C} 1$ was also evaluated in this analysis and there were no signs of instability. For this reason, no fixation to the skull as performed.

The patient was discharged on the 6th day of hospitalization, with significant neurological recovery, walking by herself, without ataxia two months following surgery, maintaining very acceptable cervical mobility (with less than $50 \%$ reduction in cervical rotation, maintaining normal flexion and extension). The control MRI showed adequate spinal decompression without any signs of other complications. (Figure 4F)

\section{DISCUSSION}

Congenital malformations of the craniocervical junction are rare and their frequently late diagnosis depends on high clinical suspicion. The embryology and possible bony malformations of the craniocervical junction are described in detail by other authors, ${ }^{10}$ and include the presence of multiple distinct configurations. In this specific case, the presence of both a defect in the fusion of the anterior and posterior arches of $\mathrm{C} 1$ and odontoid process hypoplasia/agenesis in $\mathrm{C} 2$ were found in the same patient in an extremely rare configuration. In fact, we did not find any other case with the same configuration described in the published medical

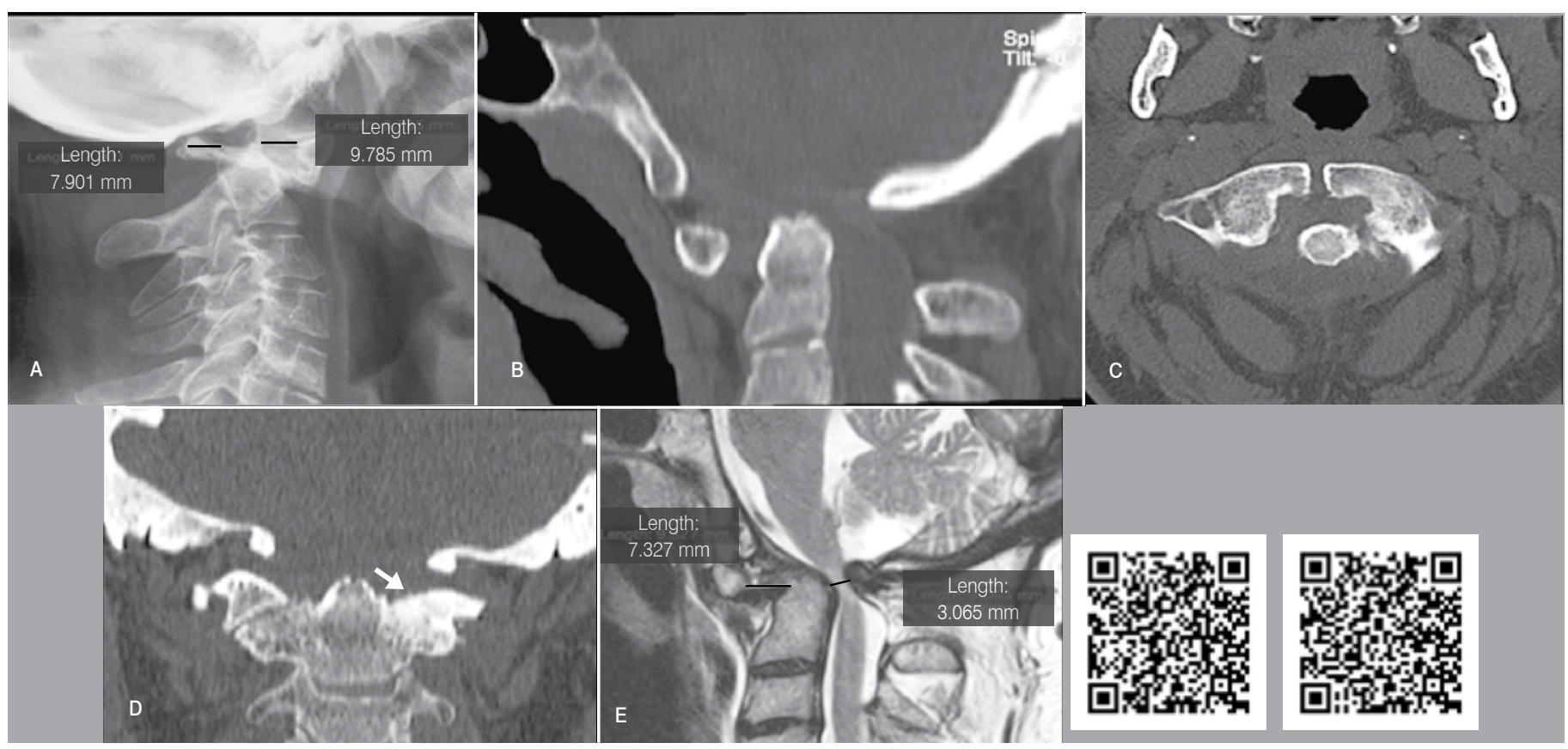

Figure 1. Preoperative exams: (A) lateral radiograph; CAT of the cervical spine in sagittal (B), axial (C), and coronal (D) sections showing severe atlantoaxial luxation and probable left C1-C2 facet arthrodesis (arrow); Cervical MRI in sagittal section showing marked spinal compression (E). 3-D videos are available by reading the $\mathrm{QR}$ codes attached. 


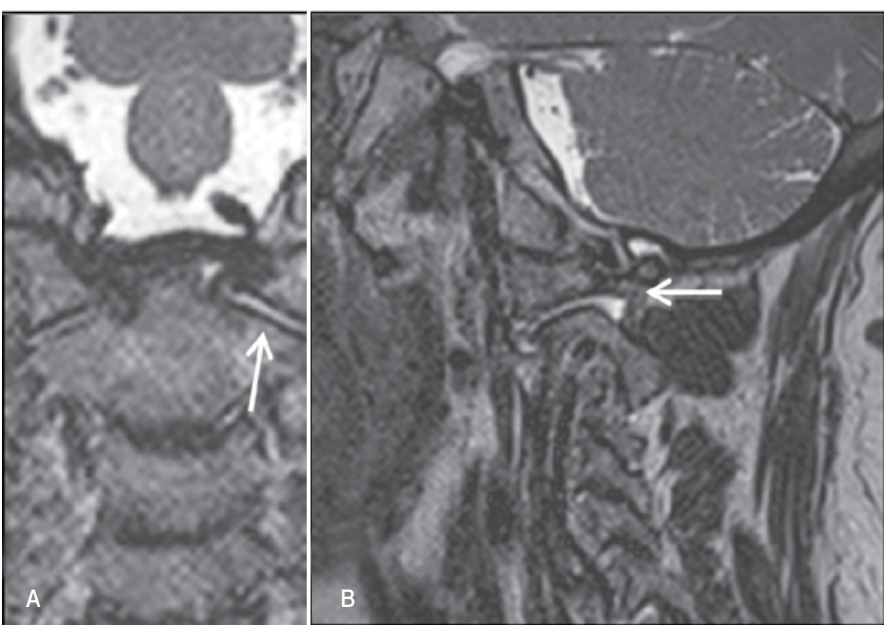

Figure 2. Cervical T2-weighted MRI in coronal (A) and para-sagittal (B) sections showing the presence of C1-C2 intra-articular fluid on the left (arrow)

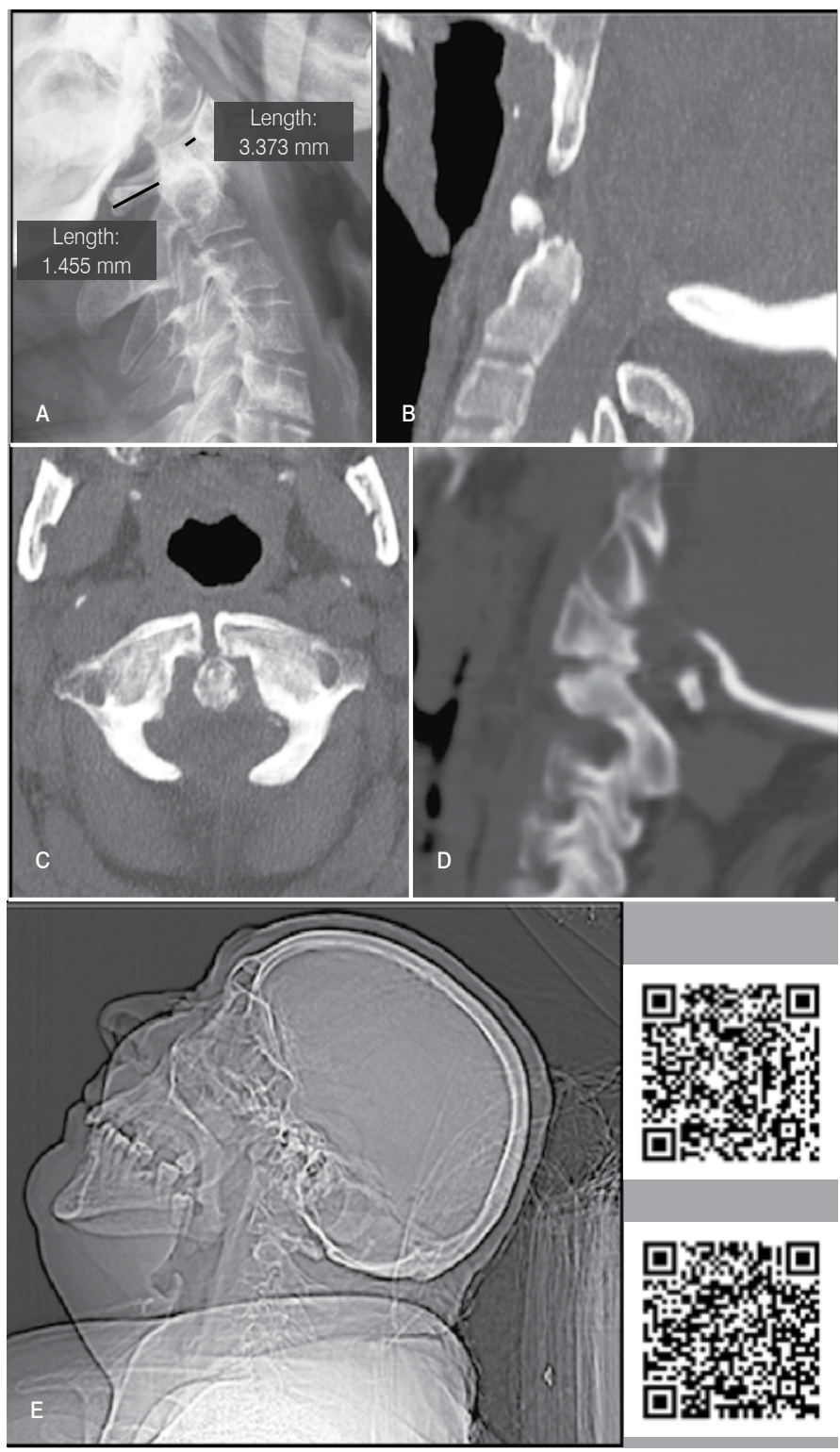

Figura 3. Exames pré-operatórios em posição de extensão: (A) radiografia e TAC-cervical (B,C e D) com redução completa da luxação atlanto-axial; (E) topograma, demonstrando o posicionamento do doente na mesa da TAC. Vídeos 3-D disponíveis através da leitura dos QR code anexos.

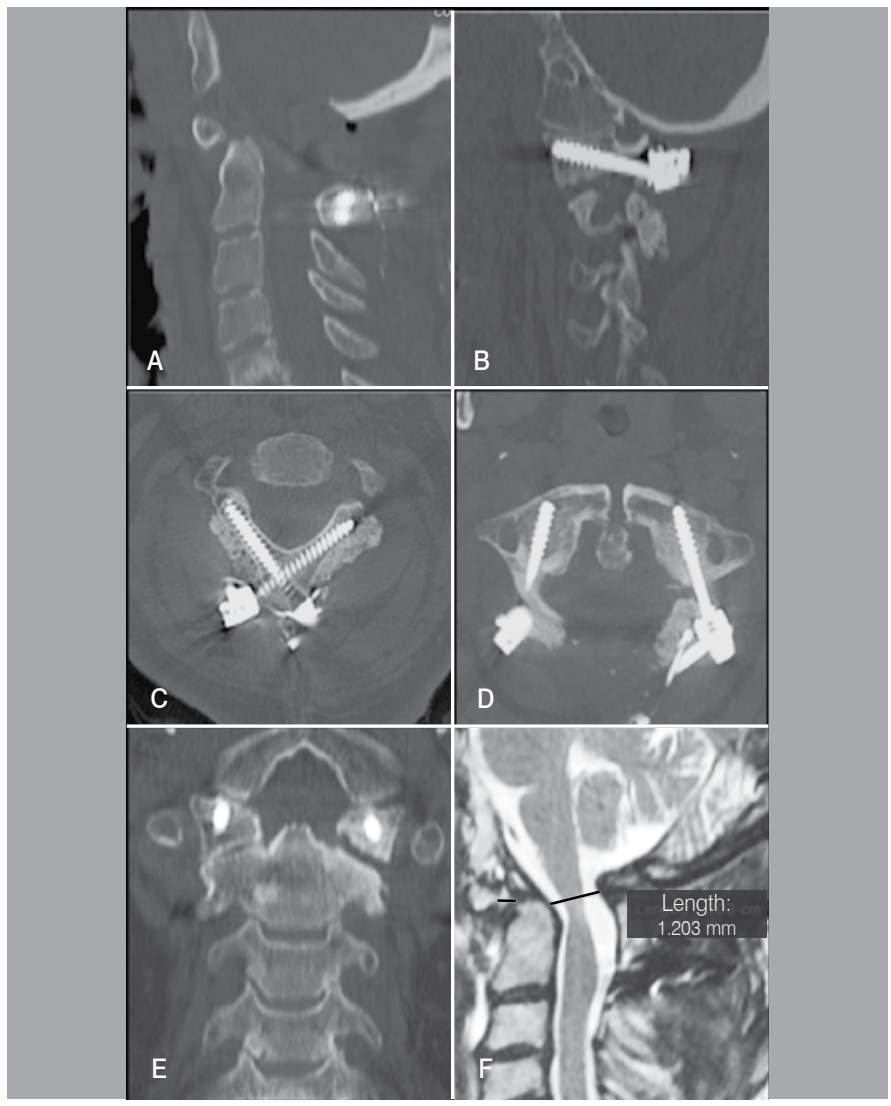

Figure 4.Postoperative images showing the characteristics of the $\mathrm{C} 1-\mathrm{C} 2$ fixation: cervical CAT in sagittal (A), para-sagittal (B), C2 axial (C), C1 axial (D), and coronal (E) sections, cervical MRI in sagittal $(F)$ section showing an increase in PADI and spinal decompression.

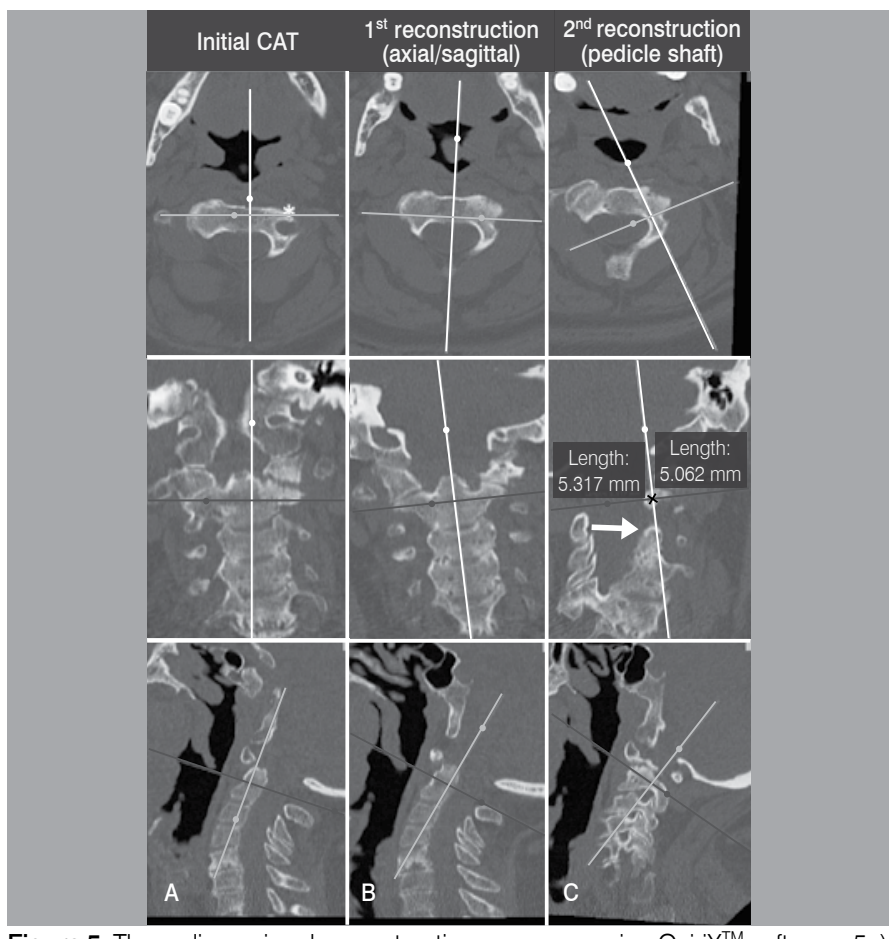

Figure 5. Three-dimensional reconstruction sequence using Osiri $\mathrm{XT}^{\mathrm{TM}}$ software: $5 \mathrm{a}$ ) In the initial CAT (spine from the left) there seems to be a high-riding vertebral artery on the left side $\left.\left({ }^{*}\right) ; 5 b\right)$ after the 1 st correction sequence for the true axial and sagittal planes, there seems to be favorable anatomy $(>) ; 5 \mathrm{c}$ ) following reconstruction for the true anatomical pedicle of $\mathrm{C} 2$, the minimum diameter was verified as $5.0 \times 5.3 \mathrm{~mm}$ (arrow), for which reason translaminar fixation was chosen. 
literature, but only rare cases of association between bipartite atlas and Os Odontoideum. ${ }^{11-13}$

The surgical approach depends on the degree and reducibility of C1-C2 instability. According to the different diagrams that have been published over the years, ${ }^{14-17}$ in cases of irreducible atlantoaxial luxations and ventral spinal compression, decompression should be performed via anterior approach (trans-oral ${ }^{17}$ or endoscopic endonasal, ${ }^{18,19}$ for example), followed by posterior craniocervical fixation in cases of acquired or iatrogenic instability. In cases of reducible lesions, only posterior fixation (with or without posterior decompression) is required. In the clinical case reported, the possibility of irreducibility was introduced by the presence of signs of fusion between the articular facets of $\mathrm{C} 1$ and $\mathrm{C} 2$ to the left and by the possible partial fusion/assimilation of the posterior arch of the atlas. The presence of intra-articular fluid and the subsequent execution of the dynamic cervical CAT demonstrate the instability and reducibility of the malformation and, additionally, confirm the absence of atlanto-occipital instability, for which reason an extension of the fixation to the skull was not performed.

Short posterior cervical fixation (such as the Harms/Goel type, for example) increases the risk of neuro-vascular complications, but offers highly efficient consolidation of the instability, maintaining a large percentage of cervical mobility. A preoperative study (three-dimensional, multiplane) is fundamental for a study of bone and vascular (vertebral artery, for example) variations of the craniocervical junction and especially for the study of adequacy of the anatomic C2 pedicle for surgical fixation. ${ }^{20}$ In this clinical case, even though the first part of the three-dimensional reconstruction with OsiriX ${ }^{\mathrm{TM}}$ software indicated an apparently favorable pedicle, the second part of the reconstruction for the true anatomic pedicle revealed dimensions at the lower limit of what is considered to be safe, (Figure 5) for which reason posterior fusion was performed according to Wright's technique, which has a lower risk of iatrogenic neurovascular lesion.

\section{CONCLUSION}

The authors report a case of surgical treatment of severe atlantoaxial instability associated with the complex malformation of the craniocervical junction, consisting of a defect in the fusion of the anterior and posterior arches of the atlas (bipartite atlas) and odontoid process hypoplasia. The use of functional/dynamic imaging techniques in addition to simple radiography permits adequate characterization of the instability and should be performed frequently, as it can change the surgical approach or technique.

All the authors declare that there are no potential conflicts of interest regarding this article.

CONTRIBUTIONS OF THE AUTHORS: Each author made an individual and significant contribution to the development of the manuscript. LM and CR were the main contributors to the writing of the manuscript. CI, LM and CR performed the surgical procedures, followed up the patients, and gathered clinical data. LM, CR and JC carried out the bibliographic review and revision of the manuscript, and contributed to the intellectual concept of the study.

\section{REFERENCES}

1. Goel A, Shah A, Rajan S. Vertical mobile and reducible atlantoaxial dislocation. Clinical article. J Neurosurg Spine. 2009;11(1):9-14.

2. Huang DG, Hao DJ, He BR, Wu QN, LiuTJ, Wang XD, et al. Posterior atlantoaxial fixation: a review of all techniques. Spine J. 2015:15(10):2271-81.

3. Currarino G, Rollins N, Diehl JT. Congenital defects of the posterior archof the atlas: a report of seven cases including an affected mother and son. AJNR Am J Neuroradiol. $1994 ; 15(2): 249-54$

4. Senoglu M, Safavi-Abbasi S, Theodore N, Bambakidis NC, Crawford NR, Sonntag VK. The frequency and clinical significance of congenital defects of the posterior and anterior arch of the atlas. J Neurosurg Spine. 2007;7(4):399-402.

5. Harms J, Melcher RP. Posterior C1-C2 fusion with polyaxial screw and rod fixation. Spine (Phila Pa 1976). 2001;26(22):2467-71.

6. Goel A, Laheri V. Plate and screw fixation for atlanto-axial subluxation. Acta Neurochir (Wien). 1994;129(1-2):47-53.

7. Wright NM. Posterior $\mathrm{C} 2$ fixation using bilateral, crossing $\mathrm{C} 2$ laminar screws: case series and technical note. J Spinal Disord Tech. 2004;17(2):158-62.

8. Dorward IG, Wright NM. Seven years of experience with C2 translaminar screw fixation: clinical series and review of the literature. Neurosurgery. 2011;68(6):1491-9.

9. Marques LM, d'Almeida GN, Cabral J. "Two-step" technique with OsiriX'M to evaluate feasibility of C2 pedicle for surgical fixation. J Craniovertebr Junction Spine. 2016;7(2):75-81.

10. Pang D, Thompson DN. Embryology and bony malformations of the craniovertebral junction. Childs Nerv Syst. 2011;27(4):523-64.

11. Weng C, Wang LM, Wang WD, Tan HY. Bipartite atlas with os odontoideum and synovial cyst: case report and review literature. Spine (Phila Pa 1976). 2010;35(12):E568-75.

12. Garg A, Gaikwad SB, Gupta V, Mishra NK, Kale SS, Singh J. Bipartite atlas with os odontoideum: case report. Spine (Phila Pa 1976). 2004;29(2):E35-8.

13. Osti M, Philipp H, Meusburger B, Benedetto KP. Os odontoideum with bipartite atlas and segmental instability: a case report. Eur Spine J. 2006;15(Suppl 5):564-7.

14. Bambakidis N, Dickman CA, Spetzler RF, Sonntag VKH. Surgery of craniovertebral junction. 2nd ed. New York: Thieme; 2013.

15. Goel A, Cacciola F. The craniovertebral junction. New York: Thieme; 2011.

16. Menezes AH, VanGilder JC, Graf CJ, McDonnell DE. Craniocervical abnormalities. A comprehensive surgical approach. J Neurosurg. 1980;53(4):444-55.

17. Dlouhy BJ, Dahdaleh NS, Menezes AH. Evolution of transoral approaches, endoscopic endonasal approaches, and reduction strategies for treatment of craniovertebral junction pathology: a treatment algorithm update. Neurosurg Focus. 2015;38(4):E8.

18. GoldschlagerT, Härtl R, Greenfield JP, AnandVK, SchwartzTH. The endoscopic endonasal approach to the odontoid and its impact on early extubation and feeding. J Neurosurg. 2015;122(3):511-8

19. Morales-Valero SF, Serchi E, Zoli M, Mazzatenta D, Van Gompel JJ. Endoscopic endonasal approach for craniovertebral junction pathology: a review of the literature. Neurosurg Focus. 2015;38(4):E15.

20. Burke LM, Yu WD, Ho A, Wagner T, O'Brien JR. Anatomical feasibility of C-2 pedicle screw fixation: the effect of variable angle interpolation of axial CT scans. J Neurosurg Spine. 2013;18(6):564-7. 